\title{
Effects of Voluntary Product Recall on Consumer's Trust
}

\author{
Luiza Venzke Bortoli ${ }^{\dagger}$ \\ Instituto Federal de Educação, Ciência e Tecnologia do Rio Grande do Sul (IFRS) \\ Valeria Freundt ${ }^{\mathbf{2}}$ \\ Insper
}

\begin{abstract}
This study analyzed the impact of voluntary product recall due to product failure on consumer's trust. Since trust is composed by integrity, competence and benevolence, this study verified the mediator effect of these constructs on the relation between recall and trust. Once trust is essential for the establishment of a relationship between companies and consumers, this research also evaluated the effects of relational and transactional purchase situations on consumer's trust and its constructs. We conducted an experimental study with a 2 (recall: control; voluntary recall) x 2 (purchase situation: relational; transactional) between subjects design. The results indicated that voluntary recall has a positive effect on the variables analyzed. Integrity and competence fully mediate the relation between voluntary recall and trust. Purchase situation moderates the effect of voluntary recall on competence.
\end{abstract}

Keywords: Voluntary recall, Product failure, Trust, Relationship, Experiment.

\section{*Author for correspondence:}

†. Instituto Federal de Educação, Ciência e Tecnologia do Rio Grande do Sul (IFRS) Address: Rua Marechal Deodoro, 1266. 96.020-220. Pelotas, RS. Brasil E-mail: luizabortoli@gmail.com

$$
\Omega \text {. Insper }
$$

The Lakes, Maeen 2, villa 98, Dubai, Emirados Árabes Unidos

E-mail: vfreundt@yahoo.com 


\section{INTRODUCTION}

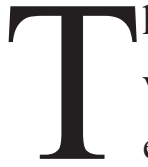

he occurrence of recall, in different segments - such as health products, food and beverages, vehicles, hygiene and beauty, children's products, computers, household appliances and electronics -, is significant over recent years (PROCON, 2015). With the globalization and spread of these recalls over the Internet (CARROLL, 2009), the effects of recall actions are greatly magnified. In a product failure context, the organization's reaction before this situation is decisive in how its consumers and other stakeholders will perceive the company and its products.

Product failures often lead to recall, which generates an impact on the organization's reputation, sales and financial value (CHEN; GANESAN; LIU, 2009). There are reactive recalls, in which the organization is obliged to promote the recall, and voluntary ones, when the organization makes a spontaneous decision in order to reverse statutory and brand image damages caused by flaws in products. Some companies adopt the voluntary or proactive strategy to respond to consumer complaints, while others are reactive (CHEN et al., 2009). Voluntary recall entails costs for the organization that implements it, as negative publicity, loss of sales, damage to its image and products, diversion of resources that would be allocated to other purposes, additional expenses with client support and threats of expenses with lawsuits filed against it.

Considering that one of organizations' concerns after a product failure is the recovery of consumer's trust (CLEEREN; DEKIMPLE; HELSEN, 2008), this study proposes to analyze the impact of voluntary recall in consumer trust. For an organization to be regarded as trustworthy, it must present competence, benevolence and integrity (MAYER; DAVIS; SCHOORMAN, 1995), therefore, we verify the mediator effect of these three attributes on the analyzed relationship. In addition, the research investigates the moderating effect of the purchase situation on the impact of recall on trust and its attributes, when there is flaw in a product.

Chen et al. (2009) indicate that voluntary recall has greater negative effect on firm value than a passive strategy does. On the other hand, Souiden and Pons (2009) indicate that a proactive strategy, as voluntary recall, has a positive impact on organizational image, loyalty and purchase intent, whereas reactive strategies have a negative effect.

Despite the costs involved in the recall process, this study examines whether conducting a voluntary recall may have positive effects on company's trust according to the consumer's perception.. It is made clear that, acknowledging faults via voluntary recalls benefits consumers and shows company's efforts towards the establishment of a trust relationship, and consequently, of its products with consumers.

Thus, this study aims to contribute theoretically with a better comprehension of the impact of voluntary recall, as a tool to correct flaws, in the company. Previous researches show the impact of recovering actions on trust (DESMET; CREMER; VAN DIJK, 2011, KIM et al., 2004). However, 
the present study differs as it deals with the impact caused by voluntary recall, in a product failure situation on consumers' trust, considering its attributes, as well as the purchase situation. This phenomenon represents a significant gap in the literature, which is filled with this study. To achieve this objective, we develop an experimental study 2 (recall: control; voluntary recall) x 2 (purchase situation: relational; transactional), considering the purchase of a defective product.

The next section exposes the theoretical framework on the topics being studied, also including the developed hypotheses. Then, we present the method and analyses and the discussion of results. Finally, we outline the conclusions, recommendations and limitations of the study.

\section{THEORETICAL FRAMEWORK}

The theoretical framework addresses the topics covered in this study, which are product recall, integrity, competence, benevolence, trust, relational and transactional purchase.

\subsection{PRODUCT RECALL}

In terms of impact on a business, a recall is considered as a reaction to a crisis situation. According to Tombs and Smith (1995), a crisis involves an event or series of events that affect the activities of a company and harms its stakeholders. A crisis brings adverse implications to operations, finances and the reputation of a company. Carroll (2009) indicates that there are different crisis modalities according to the damage they can cause in terms of profit and reputation with stakeholders. In extreme cases, the crisis may even threaten the survival and the reputation of the company.

Recall is a way for companies to deal with crisis that bring risk to consumers. A company's decision not to conduct a recall, given its knowledge of a product that could pose a hazard to the health of its consumers, hinders its reputation, sales and increases expenses with payments of indemnities for harmed consumers (CARROLL, 2009).

According to the Consumer Protection Foundation (PROCON, 2015), the recall is an action prescribed by law, adopted by suppliers to warn consumers about the need to call the consumer back, when problems with products or services placed on the consumer market are encountered. The objective of the recall is to protect and preserve life, health, integrity and consumer's safety, preventing consumption accidents, material and moral damages.

The number of recalls has increased in recent decades (PROCON, 2015). In the early 70s, the Consumer Product Safety Commission (CPSC) (2014) was created in the United States, regulating products which can bring any risk to the consumer. Its creation boosted product recalls in the American market, whether imports or not, since it requires that manufacturers, distributors 
and retailers repair, replace or reimburse products that present considerable risk. Snyder (1975), Mowen, Jolly and Nickell (1981) and Kalaignanam, Kushwaha and Eilert (2013) indicated that the expansion of recalls would be associated with increased complexity of products and a more active attitude by consumers, regarding their complaints and dissatisfactions recorded in government agencies, as the CPSC and the Food and Drug Administration, which is a regulatory body of the procedures in the food and drug industries in the United States. Chen et al. (2009) pointed out that the increase in recalls would be associated with globalization, in which the adoption of global brands widens the exposure of product failure and increases the scale of recalls. Carroll (2009) states that the internet leverages the potential damage caused by defective products or those that present risk to the consumer, since the disclosure of the symptoms caused by poisoned food in a country has global coverage on the internet. Consumers in different parts of the world, who buy the same product manufactured by another factory, can mistakenly associate symptoms they experience with the consumption of their particular product (CARROLL, 2009).

With the increasing frequency of recalls and the impact it can cause for companies in local and global scales, managing and avoiding the effects of such crisis have become a priority. There are four ways to manage the recall: denial, a legally enforced recall, voluntary recall and super effort (SIOMKOS; KURZBARD, 1994, DAWAR; PILLUTLA, 2000, LAUFER; COOMBS, 2006). In a denial situation or stonewalling, the company repudiates responsibility. In the second case, it is enforced by legal mechanisms to carry out a recall. In the voluntary recall, the object of this study, the company spontaneously decides to conduct the product recall. In extreme effort, in addition to the recall, the company will, through wide media use, admit its responsibility for the product failure and assumes the material damages that it may have caused to consumers.

There are different ways of conducting a recall. There may be a call for maintenance, product replacement for another non-defective one, discount coupons for a next purchase, financial compensation for damage due to the recall, as well as permanent or temporary withdrawal of a product from the market (DAVIDSON; WORRELL, 1992, XIE; PENG, 2009, CARROLL, 2009, CHEAH; CHAN; CHIENG, 2007).

The recall can be classified according to its speed, as fast or slow, and both pose risks. The fast recall can be precipitated and bring unnecessary high costs to the company. The slow recall alternative may allow the effects of the product's failure to become even larger and causing the company to be perceived as negligent by stakeholders (SMITH; THOMAS; QUELCH, 1996).

Studies indicate that the recall negatively affects sales (VAN HEERDE; HELSEN; DEKIMPE, 2007, CARROLL, 2009), profit potential, company's stocks valuation (BARBER; DARROUGH, 1996, GOVINDARAJ; JAGGI; LIN, 2004, CARROLL, 2009), causing losses of both the financial value of listed companies, as the intention of investors to continue financing private companies 
(DAVIDSON; WORRELL, 1992, CHEN et al., 2009). Moreover, it impacts unfavorably on the reputation, brand and expectations regarding the company conducting the recall (MOWEN, 1980, MOWEN et al., 1981, VAN HEERDE et al., 2007, CHEAH et al., 2007, CARROLL, 2009), reduces the effectiveness of advertising, increases price sensitivity, making it difficult to raise prices to recover losses on revenue and it damages the brand equity (VAN HEERDE et al., 2007, DAWAR; PILLUTLA, 2000).

Cleeren, Van herde and Dekimpe (2013) suggest that, according to the concentration and number of competitors in a market, recall of a product can affect the entire product category. Its impact on the category can affect sales, margin, negative publicity and brand equity

Chen et al. (2009) identified that, regardless of the product's nature or industry sector, a voluntary recall strategy has a greater negative effect on firms' value than a passive strategy does, as the market understands that the company conducting this operation assessed that the potential effects of the generated crisis caused by the product fault are so intense that it has no choice but to conduct the recall. However, Souiden and Pons (2009) indicate that a proactive strategy has a positive impact on organizational image, loyalty and purchase intent, whereas reactive strategies have a negative influence.

Smith et al. (1996) emphasizes the necessary precaution to implement the recall. The first concern is the time devoted to it. In addition, the planning of the operation should consider its amplitude, mechanics, speed, schedule, communication and ways of dealing with consumers who have missed the dates established for the recall. The authors also recommend monitoring the media in order to avoid that the effects of the crisis, which led to the recall, to be even worse. Lastly, Smith et al. (1996) highlights the need to analyze the effectiveness of the recall and its consequences on business results.

\subsection{THE RELATION OF INTEGRITY, COMPETENCE AND BENEVOLENCE WITH TRUST}

Product failure can lead to negative consequences for the company, one being the impact on the trust that consumers have in a particular brand. According to Poppo and Schepker (2010), the public's trust in organizations is critical to ensure its legitimacy and survival.

Mayer, Davis and Schoorman (1995) defines trust as the willingness of a party to be vulnerable to the actions of another party based on the expectation that the other will perform a particular action important to the trustor, without the need for monitoring or control. A person or entity is deemed reliable when it is perceived as having competence, benevolence and integrity. After giving an opportunity to the company, the consumer evaluates the results achieved, which can strengthen or 
weaken their confidence. When perceptions of competence, benevolence and integrity of a partner are high, this partner shall be considered as very reliable (MAYER et al., 1995). The literature on the constructs considered in this study indicates that competence and benevolence associated with integrity contribute to the development of trust (DONEY; CANNON, 1997, GANESAN; HESS, 1997, KUMAR; SCHEER; STEENKAMP, 1995).

Mayer et al. (1995) propose a conceptual model of trust that includes ability, benevolence and integrity. According to the authors, ability is the extent to which the party is deemed to have skills and competencies in the domain of interest. In this article, ability will be treated as competence. For the authors, trust stems from benevolence, competence and integrity, but these constructs are independent and do not always vary in the same direction. That is, there are relationships in which there is benevolence, but no competence, there are others in which there is competence and benevolence, but no integrity.

Competence, for Sirdeshmukh, Singh and Sabol (2002), consists in the expectation of a consistently qualified performance of a partner, a condition for the development of trust in a relationship context. Mayer et al. (1995) suggest that benevolence corresponds to a perception of a positive orientation in which one of the parties - person or organization - wishes to do good to the other without the interest in its own advantage. In a situation where there is benevolence, there should be no lies. The authors emphasize that benevolence is not sufficient for there to be trust. It needs to be combined with competence and integrity.

Murphy, Laczniak and Wood (2007) define that integrity is a virtue of all professional relationships, and has two meanings. The first meaning is related to the adherence to a moral code, and the second, to completeness/integrity. According to Koehn (2005), integrity has become an asset for businesses, and its existence is accompanied by the desire to act with care and caution.

For Poppo and Schepker (2010), an integrity violation translates an intentional transgression, an opportunism. Integrity failures can affect the esteem of the organization who commits the offense, whereas competence failures impact on consumer confidence in an organization (POPPO; SCHEPKER, 2010).

Every company is subject to possible failures that jeopardize the relationship with its customers and the repurchase. Boon and Holmes (1999) indicate that failure reveals unconformity between the expectations in relation to the other party, exposing vulnerabilities, doubts and uncertainties regarding the original perception of quality. The study by Aaker, Fournier and Brasel (2004) indicated that, despite the existence of a strong relationship, the consumer does not discount a transgression. The theory of causal attribution by Weiner (1986 apud TOMLINSON; MAYER, 2009) claims that individuals evaluate the results of their experiences as positive or negative. A failure leads individuals to identify their cause. The attribution of the cause is evaluated in three dimensions: 
i) locus of causality, that distinguishes the internal causes from the external ones or it restricts the failure to an eventual situation, ii) controllability, which refers to identifying who had control over the outcome and; iii) stability, which refers to an eventual or constant cause, thus representing, what to expect in the future under certain circumstances. After this analysis, future expectations and specific emotional reactions predict subsequent behavior. The aforementioned locus indicates where the attribution failure is focused: consumer related, manufacturer-related or seller-related (MCGILL, 1991). From the theory by Weiner (1986 apud TOMLINSON; MAYER, 2009) and the model by Mayer et al. (1995), Tomlinson and Mayer (2009) propose an association model between failure, it cause and actions to recover trust and preserve the relationship. In this model, the cause of failure can be provoked by internal or external factors or restricted to a situation, as in the case of product failure that leads to its recall. Tomlinson and Mayer's (2009) model proposes that trust can be repaired by the restoration of ability, benevolence and integrity of the institution that makes the transgression Regarding repair's announcement in order to regain public's trust after a crisis, studies by Pfarrer, Decelles and Smith (2008) and Poppo and Schepker (2010) indicate a tendency for companies to communicate failures related to competence rather than failure related to the integrity. Regarding communication, for Kim et al. (2004), organizations tend to deny integrity violations and to apologize for failures related to competence. These communication strategies result from the fact that the integrity has greater impact on trust than competence does.

This experiment suggests that, in contrast to the absence of the recall, the fact that the company recognizes its failure and conducts the recall will have a positive impact on trust. Therefore, the following hypothesis was developed:

Hypothesis 1: Trust in the organization will improve when recall is conducted as opposed to when it does not occur.

Xie and Peng (2009) propose a model in which the recovery tactic adopted by the company impacts consumer trust. After negative publicity, affective recovery efforts improve perceptions of integrity, consequently affecting trust (XIE; PENG, 2009). A word of apology in a narrative form also impacts on trust, mediated by integrity (VAN LAER; RUYTER, 2010).

The informational recovery effort is effective on trust through integrity and competence (XIE; PENG, 2009). Communication and the institutional strategic reform are needed to repair trust, but are more relevant after the violation of competence than integrity (POPPO; SCHEPKER, 2010).

Following a violation, the signals given by the promise are seen as informative for trust repair when the transgression was associated to a lack of competence (DIRKS et al., 2011). The functional repair impacts competence and consequently, trust (XIE; PENG, 2009). After negative publicity, affective recovery efforts improve the perceptions of organizational benevolence (XIE; PENG, 2009). Xie and Peng (2009) suggest that integrity and competence strengthen consumer 
confidence in the organization, whereas benevolence does not have a significant impact. Moreover, these three attributes motivate consumers forgiveness, consequently impacting on their trust.

Thus, we propose that integrity, competence and benevolence mediate the effect of the recall on trust. Thus, the following hypotheses are developed:

Hypothesis 2a: Consumer's perception over organizational integrity mediates the relationship between recall and trust in the organization.

Hypothesis 2b: Consumer's perception over organizational competence mediates the relationship between recall and trust in the organization.

Hypothesis 2c: Consumer's perception over organizational benevolence mediates the relationship between recall and trust in the organization.

\subsection{RELATIONAL AND TRANSACTIONAL PURCHASE}

The purchase decision process continually changes due to changes in consumer attitudes towards products, brands and companies. Involvement is the perceived relevance by a person toward the object, based on inherent needs, values and interests (ZAICHKOWSKY, 1985). Petty, Cacioppo and Schumann (1983) indicate that the greater the consumer's involvement, the deeper the processing of relevant information for the decision process. Blackwell, Miniard and Engel (2005) point out that the purchase decision process can be classified into three groups, according to the type of involvement in the decision and the nature of the problem in which it is involved: i) Extended problem solving (EPS), when there is detail, rigor and high involvement by the consumer; ii) limited problem solving (LPS), when the consumer does not have time or motivation to start an EPS, opting for simple paths to the final decision as a choice based on price or brand and, consequently, has little involvement in the process and; iii) intermediate problem solving (IPS) when the consumer opts for an intermediate path between the extremes of the continuum of the decision process. The chosen product for this experiment was a cell phone unit, which falls under the EPS situation, since consumers are receptive to information from various sources and devote efforts to determine the best choice.

Levine and White (1961) were first to address the importance of establishing a relationship between companies and customers. In the following years, the topic expanded to marketing services and marketing channels (ANDERSON; NARUS, 1984).

The relationship marketing concept was coined by Berry (1983) when he indicated the relevance of training and motivating the people involved in providing services to build and maintain relationships. The author defined relationship marketing as the process of attracting and 
maintaining customers and, in multiservice organizations, increasing the relationship and purchases made by them. Most relationship definitions are based on developing and maintaining a long-term relationship with consumers and stakeholders (MORGAN; HUNT, 1994, GRÖNROOS, 1994, 1997).

For Gummesson (2010), strengthening relationships constitutes one of the priority targets for managers. Berry (1983) added that the relationship marketing is grounded on attracting maintaining and enhancing, customer relationships. For Zeithmal and Bitner (2003), the main goal is to maintain a committed customer base that are profitable for the organization.

Grönroos (1991) points out that the marketing strategy rests on a continuum in which transaction marketing corresponds to an extreme, and the relationship marketing strategy represents one end of the continuum where the strategy is based on actions that facilitate exchange. On the other extreme there is, relationship marketing, where the priority is to use the resources in such a manner that the customer's trust in the organization is strengthened.

Gummesson (2010) defines that the transaction marketing involves a transactional purchase or pure transaction, occurring once. In this case, the consumer will not necessarily purchase more than once, because there is no history and memory and therefore the transaction does not become sentimental. For Webster (1992), in the transactional purchase, the exchange occurs once only, without previous or subsequent interaction. In this situation, there is no recognition of the brand, customer on behalf of the seller, preference, loyalty nor differentiation, and the price is the reference in the purchasing decision process.

One of the benefits of the relationship is the loyalty of customers and the possibility of repurchase. For Reichheld and Sasser (1990), Gummesson (2002) and Heskett et al. (2008), satisfied and loyal customers generate more revenue and higher profits for companies. Sirdeshmukh et al. (2002) suggest that the relationship is the result of trust and loyalty resulted from it. Reichheld and Schefter (2010) indicate that without trust there is no loyalty and it creates a virtuous cycle generating a competitive advantage to companies. Therefore, trust is one of the foundations of the relationship and this virtuous cycle.

We propose that the purchase situation moderates the effect of the recall on trust and its attributes so that the existence of a relationship, compared to a transactional situation, will positively impact the competence and its attributes when a recall takes place, but will have no impact on its absence. Thus, we present the hypotheses:

Hypothesis 3a: The relational situation, opposed to the transactional one, positively affects integrity when a voluntary recall takes place, but it has no impact on its absence. 
Hypothesis 3b: The relational situation, opposed to the transactional one, positively affects competence when there is a voluntary recall, but has no impact on its absence.

Hypothesis 3c: The relational situation, opposed to the transactional one, positively affects benevolence when there is a voluntary recall, but has no impact on its absence.

Hypothesis 3d: The relational situation, opposed to the transactional one, positively affects trust when there is a voluntary recall, but has no impact on its absence.

From the theoretical framework and the delineation of hypotheses, we develop the research method.

\section{METHOD}

In order to test the hypotheses presented, we adopted the experimental method.

Experimental design: The experiment was a 2 (recall: control; voluntary recall) $\mathrm{x}$ 2 (purchase situation: relational; transactional) between subject design. For the study, a scenario was developed where a cell phone device presented faults in sound quality.

Participants: In this study, 133 undergraduate Business and Administration students from two universities in São Paulo participated, of whom 62.9\% are male, with an average age of 22 years $(\sigma=2.6$ years). The scenarios were randomly assigned to participants. Each scenario had between 31 and 38 subjects.

Manipulation check: A study was conducted to verify scenarios' manipulation $(\mathrm{n}=51)$. Respondents in the recall situation $(M=5.05$; $\mathrm{SD}=1.988)$ indicated significantly higher perception of voluntary recall than those participants in scenarios without recall $(M=3.59$; $\mathrm{SD}=2.368 ; F(1,49)=5.439 ; p=0.024)$. By analyzing the purchase situation, participants in the relational scenario $(M=5.58 ; \mathrm{SD}=1.501)$ realized they had more of a relationship with the organization than those in the transactional situation $(M=1.88 ; \mathrm{SD}=1.590 ; F(1$, 49) $=72.960 ; p<0.001)$.

Realism of the scenarios: For the external validity, we verified the realism of the scenarios (The situation presented corresponds to actions taken by organizations in the real world). All scenarios obtained rating higher than 4, central point of the scale, indicating the perception of realism. There was no significant difference between the realism of the scenarios $(F(6,43)=0.735 ; p=0.624)$.

Procedures: The study invited subjects to participate in a study that aimed to analyze the behavior of cell phones users, context in which the survey was conducted. The choice of 
cell phone was due to the suitability of the product to the transactional and relational purchase situation. The participants received the information that a organization had launched a cell phone in Brazil, which had sound quality issues, a problem disclosed in the media. On the recall scenario, the manufacturer decided to conduct a voluntary recall in order to repair the issue, and on the control scenario, the company decided to ignore it and proceed with the sale of the product. The situation required the participants to consider they would have been one of the buyers of the defective cell phone device.

According to the literature, in order to depict a relational situation, the respondent was informed that he/she was a regular customer, and this was the third cell phone of the same brand purchased by him/her. In the transactional purchase situation, the respondent was informed that this was the first cell phone of this brand purchased.

Dependent variables: To measure integrity, competence, benevolence and trust we used scales adapted by Gefen (2002 apud BAPTISTA, 2005). Integrity was measured by 3 items (I believe the information I get from the organization are always correct; I do not doubt the organization's honesty (reverse item); I am sure that the organization conducts itself ethically) ( $\alpha=0.712$ ). Competence was measured by 2 items (I think the organization knows the market in which it operates very well; The organization knows how to offer excellent services) $(\alpha=0.650)$. Benevolence was measured by 5 items (The organization has policies that protect my interests as a client; When the organization makes important decisions it takes into account the clients' well-being; The organization acts as if the customer is always right; The organization has good intentions towards its customers; The organization places customer interests first) $(\alpha=0.889)$. Trust was measured by 3 items (The organization inspires me a sense of trust; I feel I can believe in the organization; I trust the company) ( $\alpha$ $=0.872$ ). The items were measured by 7 -points scales, ranging from strongly disagree to strongly agree.

\section{ANALYSIS AND DISCUSSION OF THE RESULTS}

Bellow, we present the analysis and discussion of results in accordance with the hypotheses. First, an analysis is made of the effect of recall on trust. Then, we analyze the mediating effect of trust constructs. Following that, we perform an analysis of the main effect of the type of purchase and its moderating effect on the relation between recall and trust and their attributes. We emphasize the fact that the experimental manipulations have been verified on the basis of previous tests. 


\subsection{MAIN EFFECT ANALYSIS}

The first analysis aimed to verify the effect of recall on trust. We performed an ANOVA and categorized recall as a dummy variable.

Trust: Recall has significant effect on trust $(F(1,129)=25.006 ; p<0.001)$. Recall situation $(M=3.42)$ generates higher trust level than the control one $(M=2.47)$. In line with the discussion in the literature, results show support for hypothesis 1 .

\subsection{MEDIATION ANALYSIS}

To test the mediating effect of integrity, competence and benevolence in the relationship between recall and trust in the company, we used the bootstrapping procedure, with scripts by Preacher and Hayes (2004). Recall was tested as an independent variable, trust as the dependent variable, whereas integrity, competence and benevolence were tested as mediator variables.

Integrity: The path between recall and integrity was positive and significant $(a=$ $1.0673 ; t=5.4680 ; p<0.001)$. The path between integrity and trust was also significant and positive $(b=0.7069 ; t=8.6051 ; p<0.001)$. The total effect of recall on trust was positive and significant $\left(c^{\prime}=0.9459 ; t=4.1398 ; p=0.001\right)$. The indirect effect of recall on trust was $a \times b=0.75$, and the interval of confidence (95\%), with 5,000 resampling in bootstrapping, does not include zero $(0.4760$ to 1.0885$)$. This indicates a significant indirect effect of recall on trust through integrity. The direct effect of recall on trust was not significant $(c=0.1914$; $t=0.9440 ; p=0.3469$ ), which shows that the effect of recall on trust is fully mediated by integrity.

Competence: The path between recall and competence was positive and significant $(a=0.7533 ; \mathrm{t}=3.6415 ; \mathrm{p}=0.0004)$. The path between competence and trust was also significant and positive $(b=0.8245 ; \mathrm{t}=12.3117 ; \mathrm{p}<0.001)$. The total effect of recall on trust was positive and significant $\left(c^{\prime}=0.9239 ; \mathrm{t}=3.9957 ; \mathrm{p}=0.001\right)$. The indirect effect of recall on trust was $a \times b=0.62$, and the confidence interval (95\%), with 5,000 resampling in bootstrapping, does not include zero (0.2943 to 0.9673). The direct effect of recall on trust was not significant $(c=0.3028 ; \mathrm{t}=1.8391 ; \mathrm{p}=0.0682)$, indicating that the effect of recall on trust is fully mediated by competence.

Benevolence: The path between recall and benevolence was positive and significant $(a=1.9338 ; \mathrm{t}=10.6057 ; \mathrm{p}<0.001)$. The path between benevolence and trust was also significant and positive $(b=0.8498 ; \mathrm{t}=10.3374 ; \mathrm{p}<0.001)$. The total effect of recall on 
trust was positive and significant $\left(c^{\prime}=0.9631 ; \mathrm{t}=4.2107 ; \mathrm{p}<0.001\right)$. The indirect effect of recall on trust was $a \times b=1.64$, and the confidence interval (95\%), with 5,000 resampling in bootstrapping, does not include zero (1.2215 to 2.1541). The direct effect of recall on trust was significant and negative $(c=-0.6802 ; \mathrm{t}=-2.9325 ; \mathrm{p}=0.0040)$, indicating that the effect of recall on trust is not entirely mediated by benevolence.

In addition, it is worth mentioning that trust and its attributes have high correlation. There is significant correlation between trust and integrity $(r=0.659, \mathrm{~N}=132, p<0.001)$, as well as competence $(r=0.764, \mathrm{~N}=130, p<0.001)$ and benevolence $(r=0.702, \mathrm{~N}=129$, $p<0.001)$. Additionally, there is a significant correlation between integrity and competence $(r=0.613, \mathrm{~N}=130, p<0.001)$, integrity and benevolence $(r=0.733, \mathrm{~N}=128, p<0.001)$, as well as competence and benevolence $(r=0.609, \mathrm{~N}=126, p<0.001)$.

We conducted a factor analysis containing the items of trust, competence, benevolence and integrity scales. The factorial solution reached a factor, with total variance explained to $55.7 \%$. Despite the statistical considerations, the variables can still considered as distinct from the theoretical point of view (DONEY; CANNON, 1997, GANESAN; HESS, 1997 , KUMAR; SCHEER; STEENKAMP, 1995). According to Mayer et al. (1995), these constructs are independent and will not always vary in the same direction. According to Xie and Peng (2009), in a transgression situation, recovery tactics adopted by organizations affect these constructs in different ways, leading to different impacts on trust.

Thus, our study shows support for hypotheses $2 \mathrm{a}$ and $2 \mathrm{~b}$, as integrity and competence fully mediate the relationship between recall and trust. Hypothesis $2 \mathrm{c}$ is not supported since benevolence does not fully mediate the analyzed relationship.

\subsection{MODERATION ANALYSIS}

In order to test hypothesis $3 \mathrm{a}, 3 \mathrm{~b}, 3 \mathrm{c}$ and $3 \mathrm{~d}$, purchase situation was categorized as a dummy variable.

Integrity: Recall has a main effect on customer's perception over organization's integrity $(F(1,128)=33.443 ; p<0.001)$. Integrity is significantly higher in the recall situation $(\mathrm{M}=3.73)$ than in the control one $(M=2.66)$. Relational situation $(M=3.59)$ generates a significantly higher perception of integrity than the transactional situation $(\mathrm{M}=2.91 ; F(1,128)=14.558 ; p<0.001)$. The interaction between recall and purchase situation is not significant $(F(1,128)=0.388 ; p=$ $0.534)$.

Competence: Recall has a main effect on perceived competence by the customer $(F(1,126)$ $=18.130 ; p<0.001)$. The relational situation generates higher perceived competence than the 
transactional one $(F(1,128)=17.743 ; p<0.001)$. In addition, there is significant interaction between recall and purchase situation $(F(1,126)=4.641 ; p=0.033)$. In a transactional purchase situation, recall has no impact on competence $(2.69$ vs. $3.09 ; F(1,68)=3.007 ; p=0.087)$. However, in the relational purchase situation, there is significant effect of recall on competence $(F(1,58)=15.427$; $p<0.001$, Figure 1$)$, and product recall $(\mathrm{M}=4.32)$ impacts more positively on competence than control does $(\mathrm{M}=3.08)$, according to Figure 1 .

Benevolence: We verified a main effect of recall on benevolence $(F(1,125)=124.432 ; p$ $<0.001)$, and there is greater customer's perception over organization's benevolence when there was product recall $(\mathrm{M}=4.21)$ than in case of no recall $(\mathrm{M}=2.27)$. The relational situation $(\mathrm{M}=$ $3.57)$ generates significantly more benevolence than the transactional one $(\mathrm{M}=3.03 ; F(1,125)=$ 11.834; $p=0.001)$. The interaction between recall and relationship has no significant impact on benevolence $(F(1,125)=0.216 ; p=0.643)$.

Trust: On the relational situation $(\mathrm{M}=3,59)$, trust on the organization is higher than on the transactional situation $(\mathrm{M}=2,40 ; F(1,129)=36,328 ; p<0,001)$. The interaction between recall and purchase situation has no significant impact on trust $(F(1,129)=1.017 ; p=0.315)$.

Results show the moderating effect of the purchase situation on competence (hypothesis $3 \mathrm{~b}$ ). However, other foreseen moderating effects were not confirmed (hypothesis $3 \mathrm{a}, 3 \mathrm{c}$ and $3 \mathrm{~d}$ ).

\section{FINAL CONSIDERATIONS}

This study indicated the benefits that a product recall may have on consumer's perception in a situation of product failure. The results show that conducting a voluntary recall generates positive impact on consumer's trust perceptions on an organization, in accordance with what is found in the literature (DONEY; CANNON, 1997, GANESAN; HESS, 1997, KUMAR et al. 1995). In a crisis caused by product failure, despite risks and costs associated with this strategy, conducting voluntary recall is recommended.

The findings of the experiment indicated that integrity and competence fully mediate the relationship between recall and trust. This shows that consumers' trust in the organization is related to their perceptions of integrity and competence reinforced by the company's decision to voluntarily assume the recall costs. In the mediation analysis, we emphasize the fact that benevolence does not fully mediate the relationship between recall and trust. This result is in accordance with Mayer et al. (1995), indicating that only benevolence is not enough to generate trust. Thus, it is clear that from the three constructs related to trust, integrity and competence stand out in the case of voluntary recall. 


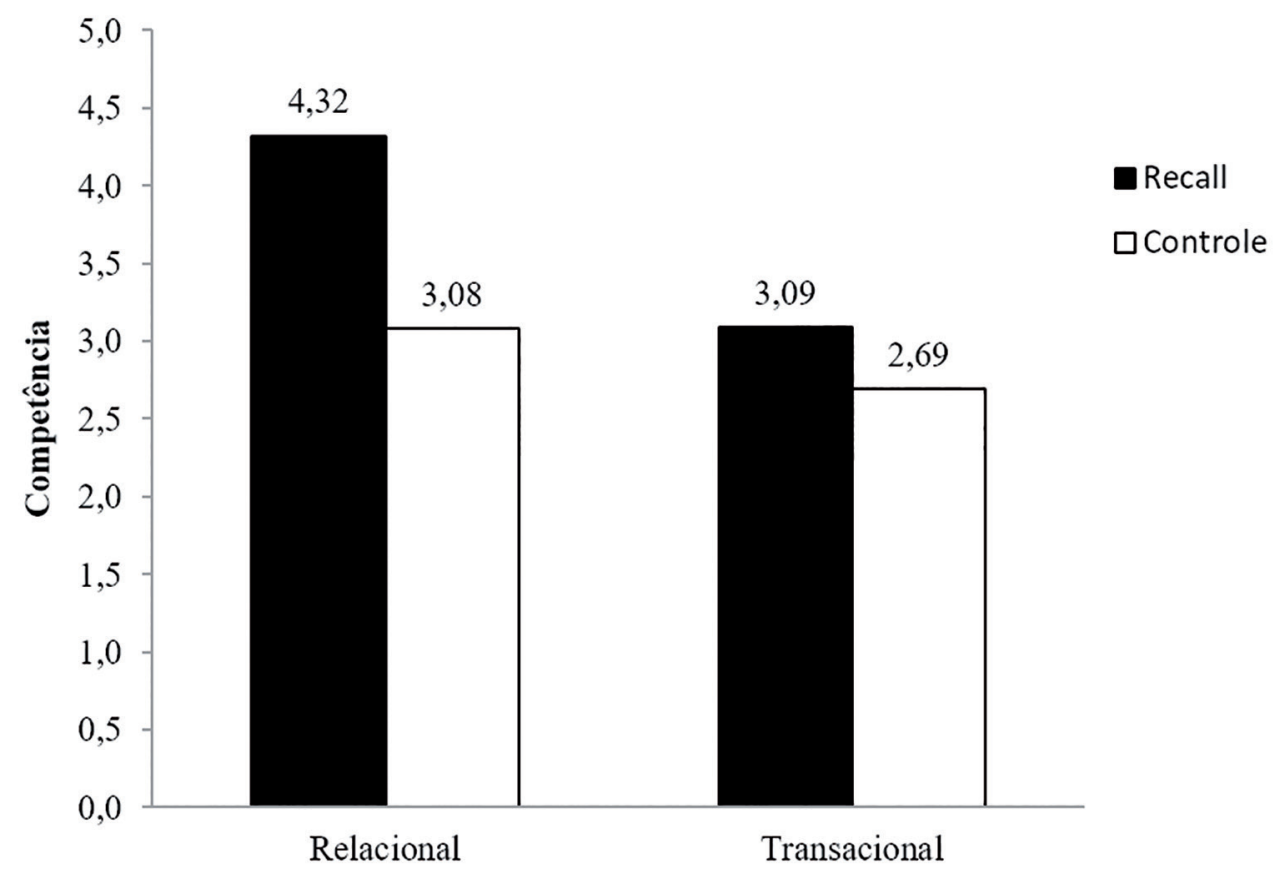

Source: Research data (2014).

Figure 1. Interaction of the recall and the competence purchasing relationship

With respect to the relationship dimension, one of the contributions of this study is the finding that the purchase situation impacts on the trust attributes.

In the relational purchase, consumers have more positive perceptions of the organization than on the transactional purchase. In addition, the relational purchase moderates the effect of recall on organization's perceived competence. On a situation of transactional purchase, the voluntary product recall does not significantly affect competence. On the other hand, in a relational purchase situation, a voluntary product recall significantly affects more positively competence than a situation without recall. The results demonstrate the relationship factor influencing consumer's evaluation. This makes sense, considering that in a transactional purchase the relation between consumers and organizations is not expected to have future developments, whereas in a relational situation, in which a long-term contact is expected, the trust relationship is more relevant.

The findings of this experiment contradict the study by Aaker et al. (2004) that, despite the existence of a strong relationship, the consumer does not forgive an organization that performs a transgression. Analyzes show that voluntary product recall and relational purchase have positive influence in recovering the perception of competence. This indicates that customers that are in a relational situation with an organization perceive the voluntary product recall as a form of recovering competence, while customers on a transactional purchase situation do not perceive the impact. The 
study also points out that only voluntary product recall may not be sufficient to improve consumer's perception of trust.

In a global and digital reality, in which consumers increasingly become aware of product recalls in different parts of the world, their expectations in a product failure situation may be that of a more drastic corrective action by the company. The voluntary product recall may not be sufficient to recover trust and the solution might be the super extreme effort recall mode (SIOMKOS; KURZBARD, 1994, DAWAR; PILLUTLA, 2000, LAUFER; COOMBS, 2006), with investments in communication being necessary in order to clarify the corrective efforts, the reasons for the failure and actions to avoid future problems with the product from repeating. However, one must take into account the recommendations regarding cautions with the communication in case of failures related to the competence and integrity (POPPO; SCHEPKER, 2010, KIM et al., 2004).

The aim of this study was to deepen and contribute to the discussion and understanding of the effects of the voluntary product recall and the relationship of organizations with consumers on trust. Despite the contributions, this research has limitations, such as the fact of considering a product recall as a single way to minimize the effects of product failure. An opportunity of research would be to evaluate other forms of companies dealing with failures or transgressions to regain trust, such as discounts on the purchase of the defective product through reimbursements, gifts or even price reductions for products purchased in the future.

In order to deepen the understanding of the results of recall on the constructs addressed, it would be favorable to conduct studies on the other three manners to deal with a crisis situation: denial, legally enforced and extreme effort recall (SIOMKOS; KURZBARD, 1994, DAWAR; PILLUTLA, 2000, LAUFER; COOMBS, 2006). Another possible topic to be studied is the effect of the recall on brand equity, since trust is related to the brand and impacts on sales volume and consumer perception in relation to other products manufactured by the company that chose to conduct the recall.

Research efforts are needed on other fronts. There are other categories of products that awaken greater sensitivity in the consumer than the product considered in this study. It is worth exploring the impact of the voluntary recall on trust and its attributes in a product category that involves greater risk to the consumer, as medicine, food or automobiles.

Another dimension future researches may explore is the risk posed by the intensity, speed and capillarity that the news propagate in social networks about their brands. Today's consumer is more demanding, better informed and stronger than before the advent of social networks. Corporate 
responsibility is therefore greater and performance failures should be avoided at all costs, investing more time and resources in tests prior to product launches.

\section{REFERENCES}

AAKER, J; FOURNIER, S.; BRASEL, S.A. When Good Brands Do Bad. Journal of Consumer Research. v. 31, n. 1, p. 1-16, June 2004.

ANDERSON, J. C.; NARUS, J.A. A Model of the Distributor's Perspective of DistributorManufacturing Working Relationships. Journal of Marketing, v. 48, n. 4, p. 62-67, Fall 1984.

BAPTISTA, P. P. Lealdade do consumidor e os seus antecedentes: um estudo aplicado ao setor varejista na Internet. Tese de doutorado, Universidade de São Paulo, São Paulo, SP, Brasil, 2005.

BARBER, B.; DARROUGH, M. N. Product reliability and firm value: The experience of American and Japanese Automakers, 1973-1992. Journal of Political Economy, v. 104, n. 5, p. 1084-1099, 1996.

BERRY, L. Relationship Marketing. In L. BERRY, G; SHOSTACK, G. U. (Eds). Emerging Perspective on Services Marketing. Chicago: American Marketing Association, p. 25-28, 1983.

BLACKWELL, R. D.; MINIARD, P. W.; ENGEL, J. F. Comportamento do consumidor: conceitos e casos. São Paulo: Pioneira Thomsom Learning, 2005.

BOON, S. D.; HOLMES, J. G. Interpersonal Risk and the Evaluation of Transgressions in Close Relationships. Personal Relationships, v.6. n. 2, p. 151-168, 1999.

CARROLL, C. Defying a Reputational Crisis - Cadbury‘s Salmonella Scare: Why are Customers Willing to Forgive and Forget? Corporate Reputation Review, v. 12, n.1, p. 64-82, 2009.

CHEAH, E.; CHAN, W.; CHIENG, C. The Corporate Social Responsibility of Pharmaceutical Product Recalls: An Empirical Examination of U.S. and U.K. Markets. Journal of Business Ethics, v. 76, n. 4, p. 427-449, 2007.

CHEN, Y.; GANESAN, S.; LIU, Y. Does a Firm's Product-Recall Strategy Affect Its Financial Value? An Examination of Strategic Alternatives During Product-Harm Crises. Journal of Marketing, v. 73, n.6, p. 214-226, 2009.

CLEEREN, K; DEKIMPLE, M. G.; HELSEN, K. Weathering product-harm crises. Journal of the Academy of Marketing Science, v. 36, p. 262-270, 2008. 
CLEEREN, K.; VAN HEERDE, H. J.; DEKIMPE, M. G. Rising from the Ashes: How Brands and Categories Can Overcome Product-Harm Crises. Journal of Marketing, v. 77, n. 2, p. 58-77, 2013.

CONSUMER PRODUCT SAFETY COMMISSION - CPSC. Disponível em < http://www.cpsc. gov/en/Search/?query=recallefilters=all>. Acesso em: 4 de abril de 2014.

DAVIDSON III, W. N.; WORRELL, D. L. The effect of product recall announcements on shareholder wealth. Strategic Management Journal, v.13, n.6, p.467-473, 1992.

DAWAR, N.; PILLUTLA, M. M.. Impact of Product-Harm Crises on Brand Equity: The Moderating Role of Consumer Expectations. Journal of Marketing Research, v.37, n. 5, p. 215-26, 2000.

DESMET, P. T. M.; CREMER, D. D.; VAN DIJK, E. In money we trust? The use of financial compensations to repair trust in the aftermath of distributive harm. Organizational Behavior and Human Decision Processes, v. 114, p. 75-86, 2011.

DIRKS, K. T.; KIM, P. H.; FERRIN, D. L.; COOPER, C. D. Understanding the effects of substantive responses on trust following a transgression. Organizational Behavior \& Human Decision Processes, v. 114, p. 87-103, 2011.

DONEY, P. M.; CANNON , J. P. An examination of the nature of trust in buyer-seller relationships. Journal of Marketing, v. 61, n. 2, p. 35-51, Apr.1997.

GANESAN, S.; HESS, R. Dimensions and levels of trust: Implications for commitment to a relationship. Marketing Letters, v. 8.n. 4, p. 439-448, Oct. 1997.

GEFEN, D. Reflections on the dimensions of trust and trustworthness among online consumer. Database for Advances in Information Systems, v. 33, p.38-53, 2002.

GOVINDARAJ, S.; JAGGI, B.; LIN, B. Market Overreaction to Product Recall Revisited-The Case of Firestone Tires and the Ford Explorer. Review of Quantitative Finance and Accounting, v. 23, n. 1, p. 31-54, Jul. 2004.

GRÖNROOS, C. The Marketing Strategy Continuum: Towards a Marketing Concept for the 1990s. Management Decision, v. 29, n.1, p. 7-13, 1991.

GRÖNROOS, C. From marketing mix to relationship marketing: towards a paradigm shift in marketing. Management Decision, v. 32, n. 2, p. 4, 1994.

GRÖNROOS, C. Value-driven Relationship Marketing: From Products to Resources to Values. Journal of Marketing Management, v. 13, n. 5, p. 407-420, Jul.1997. 
GUMMESSON, E. Relationship Marketing in the New Economy. Journal of Relationship Marketing, v. 1, n. 1, p. 37-57, 2002.

GUMMESSON, E. Marketing de relacionamento total: gerenciamento de marketing, estratégia de relacionamento e abordagens de CRM para a economia de rede (2a ed.). Porto Alegre: Bookman, 2010.

HESKETT, J. L.;JONES, T. O.; LOVEMAN, G. W.; SASSER W. E.; SCHLESINGER, L. A. Putting the Service-Profit Chain to Work. Harvard Business Review, v. 86, n. 7/8, p. 118-129, Jul-Aug. 2008.

KALAIGNANAM, K.; KUSHWAHA, T.; EILERT, M. The Impact of Product Recalls on Future Product Reliability and Future Accidents: Evidence from the Automobile Industry. Journal of Marketing, v. 77, n. 2, p. 41-57, Mar. 2013.

KIM, P. H.; FERRIN, D. L.; COOPER, C. D.; DIRKS, K. T. Removing the Shadow of Suspicion: The Effects of Apology Versus Denial for Repairing Competence- Versus Integrity-Based Trust Violations. Journal of Applied Psychology, v. 89, n. 1, p. 104-118, Feb. 2004.

KOEHN, D. Integrity as a Business Asset. Journal of Business Ethics, v. 58, n. 1-3, p. 125-136, Apr. 2005.

KUMAR, N.; SCHEER, L. K.; STEENKAMP, J. B. The effects of perceived interdependence on dealer attitudes, Journal of Marketing Research, v. 32, n. 3, p. 348-356, Aug. 1995.

VAN LAER, T; DE RUYTER, K. In stories we trust: How narrative apologies provide cover for competitive vulnerability after integrity-violating blog posts. International Journal of Research in Marketing, v. 27, n. 2, p.164-174, 2010.

LAUFER, D.; COOMBS, W. T. How Should a Company Respond to a Product Harm Crisis? The Role of Corporate Reputation and Consumer-Based Cues, Business Horizons, v. 49, n.5, p. 379385, Sep./Oct. 2006.

LEVINE, S.; WHITE, P. Exchange as a Conceptual Framework for the Study of Interorganizational Relationships. Administrative Science Quarterly, v. 5, n. 4, p. 583-601, Mar. 1961.

MAYER, R. C.; DAVIS, J. H.; SCHOORMAN, F. D. An integrative model of organizational trust. Academy of Management Review, v. 20, n. 3, p. 709-734, Jul. 1995.

MORGAN, R. M.; HUNT, S. D. The Commitment-Trust Theory of Relationship Marketing. Journal of Marketing, v. 58, n. 3, p. 20-38, Jul. 1994. 
MCGILL, A. L. Predicting Consumers' Reactions to Product Failure: Do Responsibility Judgments Follow from Consumers' Causal Explanations? Marketing Letters, v. 2, n. 1, p. 59-70, Jan. 1991.

MOWEN, J. C., Further information on consumer perceptions of product recalls. Advances in Consumer Research, v. 7, n. 1, p. 519-523, 1980.

MOWEN, J. C.; JOLLY, D.; NICKELL, G. S. Factors influencing consumer responses to product recalls: a regression analysis approach. Advances in Consumer Research, v. 8, n. 1, p. 405-407, 1981.

MURPHY P.; LACZNIAK G.; WOOD G. An ethical basis for relationship marketing: a virtue ethics perspective. European Journal of Marketing, v. 41, n. 1/2, p. 37-57, 2007.

PETTY, R.; CACIOPPO, J.; SCHUMANN, D. Central and Peripheral Routes to Advertising Effectiveness: The Moderating Role of Involvement. Journal of Consumer Research, v. 10, n. 2, p. 135-146, Sep. 1983.

PFARRER, M.; DECELLES, K.; SMITH, K. After the fall: Reintegrating the corrupt organization. Academy of Management Review, v. 33, n. 3, p. 730- 749, Jul. 2008.

PREACHER, K.; HAYES, A.SPSS and SAS procedures for estimating indirect effects in simple mediation models. Behavior Research Methods, Instruments, \& Computers, v. 36, n. 4, p. 717 731, Nov. 2004.

POPPO, L.; CHEPKER, D. J. Repairing Public Trust in Organizations. Corporate Reputation Review, v. 13, n. 2, p. 124-141, 2010.

PROCON. Recall Chamamento. Disponível em: <sistemas.procon.sp.gov.br/recall>. Acesso em: 6 de janeiro de 2015.

REICHHELD, F. F.; SASSER JR, W. E. Zero defections: Quality comes to services. Harvard Business Review, v. 68, n. 5, p. 105-111, Sep./Oct. 1990.

REICHHELD, F. F.; SCHEFTER, P. E-Loyalty. Harvard Business Review, v. 78, n. 4, p. 105-113, Jul./Aug. 2000.

SIOMKOS, G. J.; KURZBARD, G. The Hidden Crisis in Product-harm Crisis Management. European Journal of Marketing, v. 28, n. 2, p. 30-41, 1994.

SIRDESHMUKH, D.; SINGH, J.; SABOL, B. Consumer Trust, Value, and Loyalty in Relational Exchanges. Journal of Marketing, v. 66, n. 1, p. 15-37, Jan. 2002. 
SMITH. N. C. R.; THOMAS, J.; QUELCH, J.. A Strategic Approach to Managing Product Recalls, Harvard Business Review, v. 74, n. 5, p. 102-113, Sep/Oct. 1996.

SNYDER, J. D, How to survive a product recall. The Marketing Magazine, v. 64, n. 2, p. 38-41, Feb. 1975.

SOUIDEN, N; PONS, F. Product recall crisis management: the impact on manufacturer's image, consumer loyalty and purchase intention. Journal of Product \& Brand Management, v. 18, n. 2, p. 106-114, 2009.

TOMLINSON, E. C.; MAYER, R. C. The role of causal attribution dimension in trust repair. Academy of Management Review, v. 34, n. 1, p. 85-104, Jan. 2009.

TOMBS, S.; SMITH, D. Corporate Social Responsibility and Crisis Management: the democratic organisation and crisis prevention. Journal of Contingencies \& Crisis Management, v. 3, n. 3, p. 135-149, Sep. 1995.

VAN HEERDE, H.; HELSEN, K.; DEKIMPE, M. The Impact of a Product-Harm Crisis on Marketing Effectiveness. Marketing Science, v. 26, n. 2, p. 230-245, Mar./Apr. 2007.

WEBSTER, F. The changing role of marketing in the corporation. Journal of Marketing, v. 56, n. 4, 1992 .

WEINER, B. An attributional model of motivation and emotion. New York: Springer-Verlag, 1986.

XIE, Y.; PENG, S. How to repair customer trust after negative publicity: The roles of competence, integrity, benevolence, and forgiveness. Psychology \& Marketing, v. 26, n. 7, p. 572-589, Jul. 2009.

ZAICHKOWSKY, J. L. Measuring the involvement construct. Journal of Consumer Research, v. 12, n. 3, p. 341-352, Dec. 1985.

ZEITHMAL, V. A., BITNER, M. J. Marketing de serviços com foco no cliente. $2^{\mathrm{a}}$ ed. Porto Alegre: Bookman, 2003. 